\title{
FUNGID: a Web-based Identification Program for Phytophthora
}

\author{
Ali Chenari Bouket \\ Department of Plant Protection, \\ Faculty of Agriculture, University \\ of Tabriz, 29 Bahman \\ Boulevard, University of Tabriz, \\ Tabriz, Iran
}

\author{
Mahdi Arzanlou \\ Department of Plant Protection, \\ Faculty of Agriculture, University \\ of Tabriz, 29 Bahman \\ Boulevard, University of Tabriz, \\ Tabriz, Iran \\ Amin Khodabande \\ OmniNet of Baran \\ (Computer and IT \\ Knowledge-based \\ Corporation), \\ Tabriz, Iran
}

Asadollah Babai-Ahari

Department of Plant Protection, Faculty of Agriculture, University of Tabriz, 29 Bahman

Boulevard, University of Tabriz, Tabriz, Iran

\begin{abstract}
The genus Phytophthora encompasses economically important plant pathogens. To date, up to 90 species have been described in this genus. There is no comprehensive key available for the identification of the all described Phytophthora species. This paper, describes a web-based identification tool (which has been described by the authors under the name of Fungid) that uses morphologic features. The characters used are the same as the synoptic keys of Gerrettson-Cornell (1994) and Ho (1981) [1, 2]. For the isolate in question, the software compares the unknown isolate with more than 40 known species submitted in the database. One or more than one species is suggested to the user by the software. For some of the species, additional data such as images of the species, links to other databases like that Q-bank, Index fungorum is presented.
\end{abstract}

\section{General Terms}

Characters, Index Fungorum, Pathogen, Q-bank, Synoptic Keys

\section{Keywords}

Database, Morphologic features, Fungid, Web-based software

\section{INTRODUCTION}

Biodiversity is the study of the variety of living beings [3]. There are several concepts presented for species definition in literatures, while some of these concepts are theoretical, with little value for species recognition; the others are practical or a combination of both with significant value for species recognition. However, a single definition which could be applied to distinguish all domains of life is not available. The morphological species concept has widely been used by biologist in order to explore the biodiversity of different groups of organism at taxonomic level of interest. It is based on the idea that a morphological type or individual can represent the variation within the populations of an entire species. Two primary criteria for species definition under morphological species are the consistency within the species and sharp splits in consistency between species. Morphologically-based species concepts and taxonomies are useful for many purposes and serve as useful tools for initial classification of biodiversity. As pointed out by many scientists, the major strengths of the morphological species concept for fungi are the general applicability of this concept to any fungal taxon and its widespread and historical use [4]. Even though, with the advent of molecular techniques and rapid progress in gene and genome sequences technologies, DNA based approaches are becoming as a gold standard technique for species recognition in fungi, the usefulness of morphological criteria for species recognition in fungi are vital and morphological discrimination at species level is important for end users such that agriculture, medical, industry and etc.

The basis of any study of biodiversity is morphological description of the existing species as they appear to us. Such descriptions must make it possible to identify other specimens of described species. Once this done, other aspects of the well characterized species such as its biology, ecology, genome and the other potentials can be studied. But, except for some unicellular organisms such as viruses, certain bacteria and etc, the basis of all these studies will always be the morphological description, of the species [5]. The large scale identification must be done by biologists who are not professional taxonomists. It is argued that printed identification aids are too rigid and unreliable, and molecular identification aid is too limited. Only computer identification tools are flexible, reliable and general enough to give a non-taxonomist the possibility to identify any species [3]. Our knowledge about morphology and the various other scientific fields represent an enormous amount of facts, which must be classified and stored in a way that supports easy retrieval. This is particularly true if the various experts that are interested in biodiversity want to be able to access data in fields with they are not familiar. Only computer science offers some hope to put this huge mass of knowledge in order and store it in such a way that the data of interest can be retrieved easily [6]. Identification of fungal plant pathogens is commonly done using one of several well-illustrated dichotomous keys $[7,8$, $9,10,11]$. Multi-access keys are very useful for biological agents, especially for non-specialists, as it is not necessary to be able to detect all of the fine descriptions usually found in dichotomous keys [12]. The disadvantages of those printed keys are that they require the user to be able to scan a series of 
tables of numbers and select those are common to the specimen being examined $[13,9]$. If a universal data format were established for the descriptions and illustrations or photos of new species and used in a database freely accessible through the internet together with properly designed software, such as a database could allow any scientists with minimal training in fungi morphology to identify the specimens they are working on. For example, the multi-access lucid key to common plant pathogenic fungi causing diseases of temperate crops

(http://plantprotection.massey.nz/resources/software/lucid_key.thm ) or Q-bank (www.q-bank.eu/Fungi) are published in the web. Some of desktop-based programs that developed in plant mycology are: TAXADAT [14]; Simple computer program prepared by Polonelli et al. (1985) [15]; PENNAME [16]; FUSKEY [17]; PENIMAT [18]; CD-ROM designed by Sarma et al. (2000) [19]; FRIDA [20]. Identification keys for the computer are not always faster than printed ones [21], particularly if non-metrical data are used. A printed key can easily be used next the microscope, but the combination of microscope and computer necessary for utilization of identification software has only recently been applied [22]. In this paper, the concepts we will present, have been developed over the last 2 years by a team consisting of the present authors, three mycologists (ACB, MA and $\mathrm{AB}$ ) and one computer engineer (AK). The project was called Fungid (Fungi Identification Program). We believe that our software could readily be extended to the identification of other biological groups. In this study, we prepare the Phytophthora section but the completion of its details will be gradual and time-consuming work.

Phytophthora (Plant destroyer) is an oomycete and the cause of the potato blight. Phytophthora caused Irish famine in 1845 [23]. Since the description of the genus Phytophthora by de Bary, over 90 species have been described in the past 100 years. Different criteria have been used to classify members of this fungi-like plant pathogenic genus The first key, by Rosenbaum (1917) [24] included 11 species and was entirely based on morphological characteristics. A later key, by Leonian (1925) [25] was instead based on physiological data. Other schemes, by Tucker (1931), Leonian (1934), Sarejanni (1936), Frezzi (1950), Waterhouse and Blackwell (1954), Waterhouse (1963), Newhook et al. (1978), Ho (1981) and Gerrettson-Cornell (1994) made use of one or both types of characters, especially morphological $[26,27,28,29,30,31$, $32,2,1]$. In spite of its comparatively small number of taxa, the genus Phytophthora has proven very difficult to classify because of the great variability exhibited by many species, the lack of a standard methodology for characterization and the limited information provided in many descriptions of species. A significant hindrance in Phytophthora studies has been the difficulty of finding media of standard composition to be used for the description of all named species and its accounts for the natural organic media mostly used by researchers in this field. The aim of this work has been to combine most of the available published taxonomically useful information on each of 41 species of Phytophthora of major importance in forestry and agriculture and to represent a user-friendly web-based identification key in order to facilitate quick diagnosis of plant pathogenic fungal or pseudo-fungal agents. This work includes a computer aid based mostly on morphological attributes.

\section{METHODS}

The program was developed in ASP.NET web language. The database was supported by SQL-Server. Fungid is freely accessible through the web, www.fungid.info . In the software for the each species of the genus Phytophthora, morphological characters (as characters and character states) were defined. These diagnostic features include: Mycelial growth, Cardinal temperatures, Hyphal swellings, Chlamydospores, Sporangiophores, Sporangia with more than one apex, Zoospores, Sexuality, Oogonia, Oospore and Antheridia. Details of morphologic attributes, used in Fungid are presented in Table 1. In this program, there is no limitation for the definition of other fungal groups. all species of all genera of fungi. Fungid is very user-friendly and can be extended to other types of living such as insects, plants, bacteria and etc. -More information about the species is in wiki-page of each species.

Table1. Morphological attributes used in Fungid

\section{DESCRIPTION OF THE USER INTERFACE}

In Fungid homepage (www.fungid.info ), there are two main icons, Go to Database and Search in Database (Fig. 1).

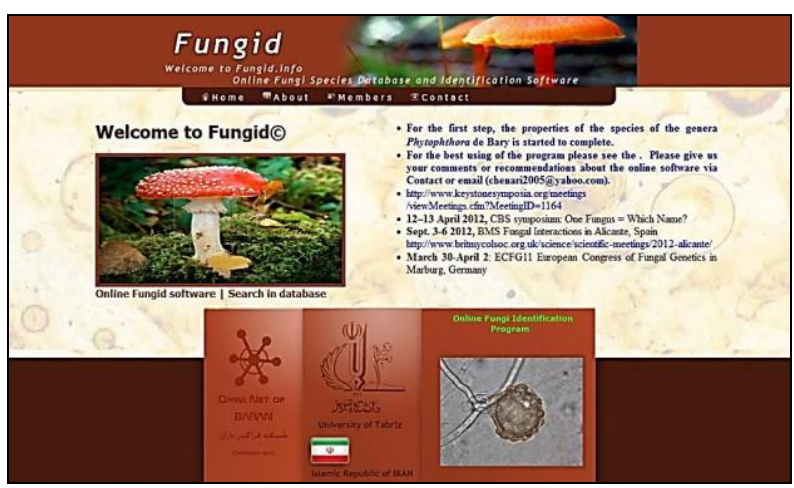

Fig. 1. Homepage of the Fungid.

In the first menu, the users must fill in the form with his/her username and password to enter and see the database contents. Certain of ID for users are supported by Administrator of the website. Users must send their request to receive the ID through the Contact menu. After log in, users can see the contents of the database such as Search, Scan, Genera and User icons without any possibility to edit or delete them (Fig. 2).

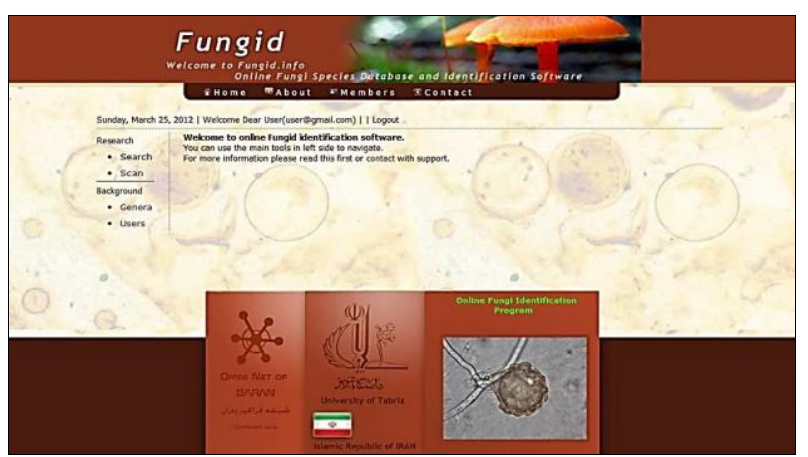

Fig. 2. Database layout of the Fungid. 
In Search icon, the user can do a general exploring based on the fungus name and find it (Fig. 3).

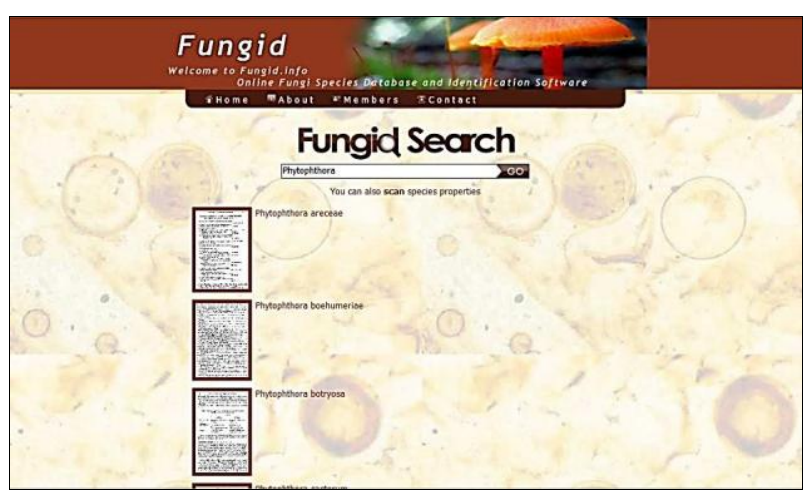

Fig. 3. The Search section of the program.

In Scan icon (the most important icon of the program), the user can choose the genus name via a combo-list. After selecting the genus and clicking on Go, the user can fill in the form of the Scan page which is based on morphological features. None of the characters were defined as a required matter. By mouse clicking on Scan, the software compares the entry with submitted information in the database and finally, one or more than one species are proposed to the user (Fig. 4).

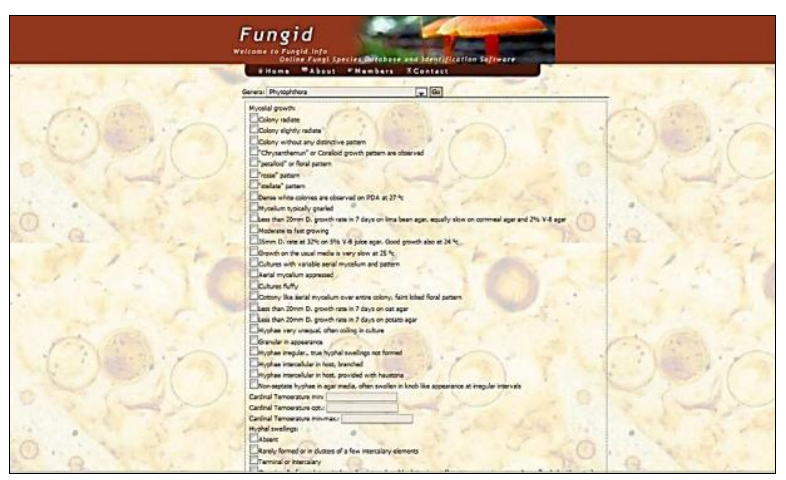

Fig. 4. The Scan section with a form that the user must fill in with morphological features of the unknown species. None of the characters were defined as required icons.

Based on the species details, the user can decide to choose the most similar species that it is highly matched to his/her isolate (Fig. 5).

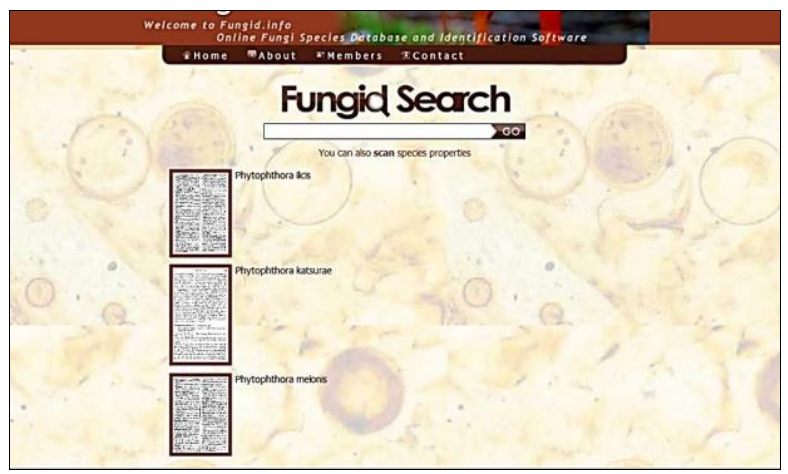

Fig. 5. Search result page of the program.
We try to complete the details of the species via adding the descriptions and images. One of the major limitations in the creating web documents is copyright. Many copyright holders are reluctant to permit use of their images, because anyone can save the image to a file on their computer and use it later without obtaining permissions [33]. Although, we linked each species to useful websites like that Q-bank and Index Fungorum. So our trying to complete the program will be a gradual work. In Genera icon, user can see the genera that have been defined to the program with their species. Some of Genera labeled with "in progress" and/or "Forthcoming", that it means the process of completeness of the genera are not finished and it is under maintenance and the process of preparation of the genera and its species will start soon (Fig. 6).

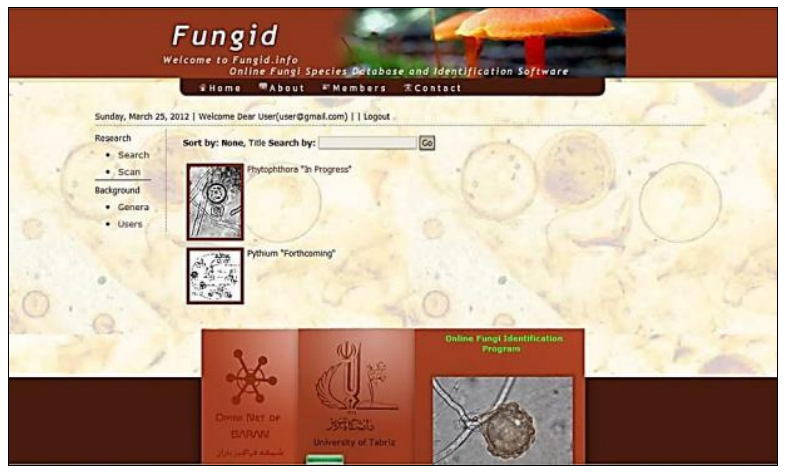

Fig. 6. The Genera section of the program.

In both genera and species with clicking on the name of the fungus, a page is opened as "wiki page". In this page, properties of the genera and species are present. In User icon, every user can see her/his profile and complete and/or edit it and can see the database of the genus. A hypothetical user ID of the site is: email: user@gmail.com; Password: user2012.

\section{RESULTS}

A serious problem in biodiversity studies is the limited availability and accessibility of data which are widely spread in several books, journals and off-line databases, as well as stored in biological collections, making it very time consuming to compile the necessary information. So, we consider Fungid is a useful tool for the rapid and accurate identification of fungi. Structure of the Fungid and how-towork of the program is presented in Fig. 7. By the way, the program can be extended to some other icons such as gene sequence search without substantial costs. In fact, polyphasic taxonomy is better than monophasic only based on morphologic or molecular characters. But, molecular data is not always available. In contrast, morphologic features are easier to obtain in comparison with molecular data.

\section{DISCUSSION AND CONCLUSIONS}

Since Fries (1921) [34] wrote his Systema Mycologicum, mycologists have tried to make accurate descriptions of the fungi they collected and to provide non-mycologists with useful identification keys. Their efforts have led to a knowledge of the most important, mainly morphological characters necessary to describe fungi and also to the different types of identification keys in use today. So far the synoptic keys and the dichotomous keys are the tools which allow 
mycologists to attempt the identification of living organisms to species level.

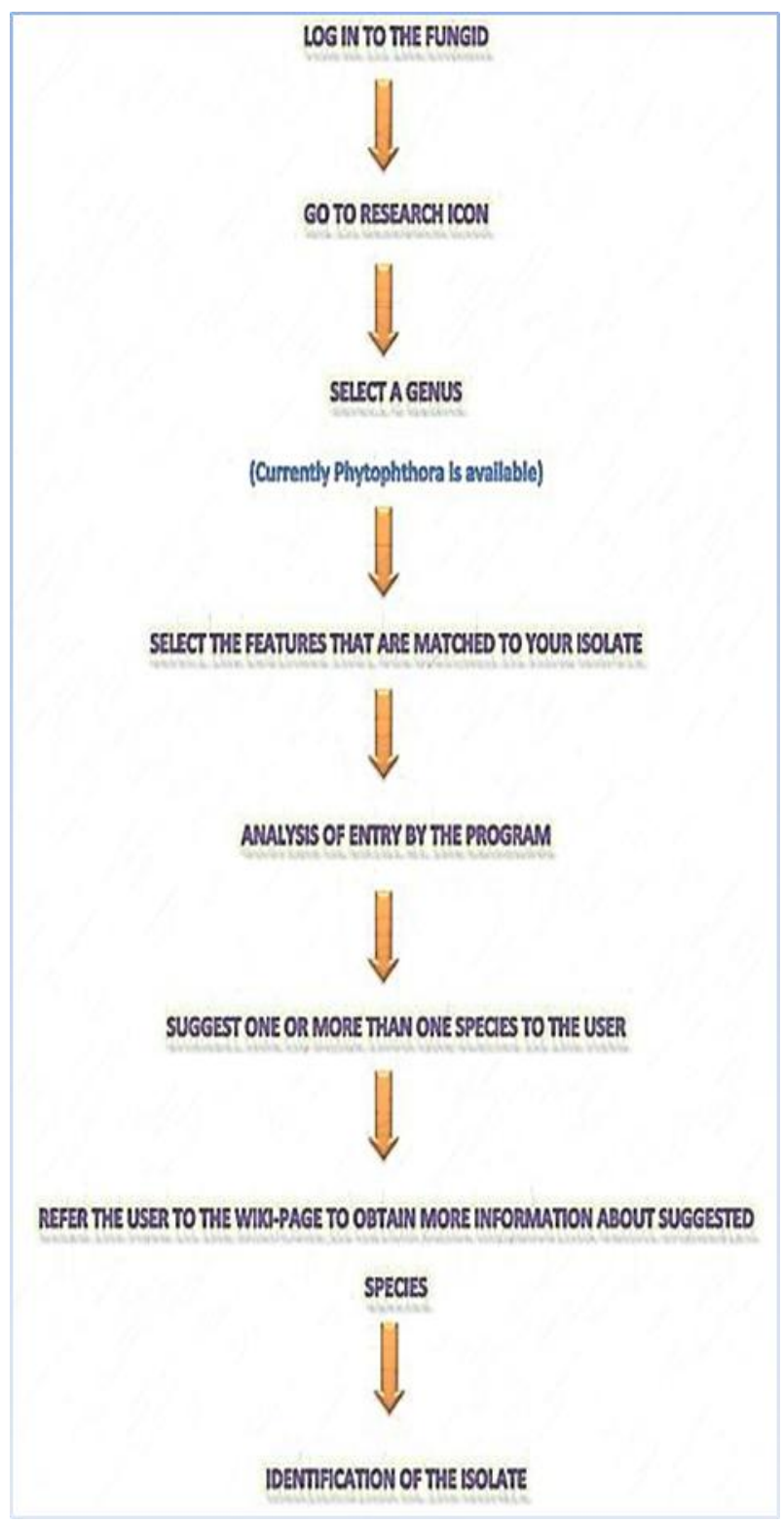

\section{Fig. 7. Structure of the Fungid and how-to-working of the program}

The synoptic key is based upon the simultaneous check of several characters and upon the elimination of the taxa not representing such features until only one taxon is left; a dichotomous key is based on a binary form of hierarchical decision-making process in which a question-making process in which a questions has to be answered by a 'yes' or 'no' in order for the next branch of the binary tree to be chosen. Both types of the keys are exhaustively discussed by Hawksworth (1974) [35] and examples of both types can be found in Sutton (1980) [9]. The use of either type of key presents specific problems. While the synoptic key is comparatively free of any kind of weighting of characters by the author, the choice of the hierarchical line of the identification steps within a dichotomous key is mainly subjective and can often lead to wrong decisions depending upon the accuracy of the choice and the skills of the user. On the other hand, the morphological and physiological characters used can be either ill-defined or not very accurate, most of them being subjectively defined by the taxonomists: particularly with a dichotomous key a considerable amount of information is presented in the form of disjunctive (OR), conjunctive (AND) and even mixed (AND/OR) sorting or by subjectively defined frequencies of occurrence (rarely, often, etc). The identification of a fungus is thus a task which can offer many problems to the inexperienced mycologist in spite of the considerable amount of information collected over the last two centuries. The availability of a computer-assisted way such as web-based program to overcome these difficulties would be of great interest to most biologists, e.g. ecologists, plant pathologists, food microbiologists, who are confronted during their work with the identification of fungi.

Printed keys are powerful tools that can be used safely since they rely on primary identification characters [36]. The paper is a dead medium that cannot be updated, but an electronic medium offers the flexibility needed to give at least some control to the user and to make it easier to update a key [3]. Computer-aided can create a revolution, since they use in a multi-dimensional way, a wealth of morphological and physiological data plus ecological information usually hidden in the large ocean of scientific literature. Traditional keys have several drawbacks that can be avoided by computer aid tools: 1) Being printed on paper, their content is frozen and hence nomenclature-taxonomic changes and the discovery of new species render them rapidly outdated. Computerized systems, on the contrary, can be updated and corrected in real time. 2) Traditional keys are rigid. They contain a huge of information which is fixed into the format and the logical structure selected by the author. Computerized tools permit to reduce the set of organisms using different combinations of morphological, ecological, distributional characters i.e. special habitats, mycotoxin production and physiological features (temperature, water activity, $\mathrm{pH}, \ldots$... 3) A small database can be the starting point for future expansions. 4) Outputs can be edited in several different formats, from simple texts to illustrated books [20]. Some of desktop computer identification tools with their approach and scopes are : TAXADAT [14] and a simple computer designed by Polonelli et al. (1985) [15], differentiation Candida albicans strains based on of the production of killer toxins by each individual strain; PENNAME [16], large synoptic key for identifying 70 common Penicillium species; FUSKEY [17], data matrix of approx 1200 Fusarium isolates using DELTA system software and key generating program INTKEY, Fusarium; PENIMAT [18], probabilistic matching, terverticillate Penicillium; CD-ROM designed by Sarma et al. (2000) [19], interactive keys linked to descriptions and images of fungi, mangrove fungi; FRIDA [20], interactive tool for the identification of fungi is written in PL/SQL language, running on a Oracle database engine, airborne and food fungi.

The web-based identification programs have many advantages over the desktop-based programs of the late 1980s. First, household computer usage for example in U.S increased from $22.8 \%$ in 1993 to $61.8 \%$ in 2003 [37]. In addition, broadband internet access is becoming more common, and wireless internet success via cell technology allows access for users in remote areas. Increasingly, common smart phones also provide internet access without the expense or weight of the laptop; users can either directly access the websites or have news emailed to their phone. Another factor favoring webbased systems is the ability to access and integrate or complete data from widely separated locations. For example, definition of many administrators for the web sites as editors 
is possible. So, several editors probably around the world can edit their data in the Fungid and in the other hand, simultaneous completeness of the program will happen. Perhaps, the greatest advantage of the web-based program over the desktop-based is that changes in the details of database at the server instantly propagated to all users at the next $\log$ in. So, errors can be quickly corrected without having to send out notices the users need to update their systems.

Our aim by designing this software is to facilitate the identification of fungal species and to present and further develop software which is easy to handle, useful and easy to obtain (via World Wide Web: www.fungid.info). This simple aim also implies a development for the near future; Fungid will not only support the identification key of the genus Phytophthora, but also of the other genera such as Pythium, Pestalotiopsis, Colletotrichum and etc. Existing printed references or desktop computerized identification tools cannot be trusted to non-taxonomists for identification of all the materials collected. A freely accessible identification tool via internet such as the one outlined here, probably can solve this problem.

The biggest technical problem to date has been related to different web browsers. Most of open source browsers have few problems. Among these, such as Mozilla Firefox, Internet Explorer, Maxthon and Google Chrome, Mozilla Firefox has a high compatibility with Fungid. Probably, several changes in settings of other browser must be done to ensure compatibility with Fungid.

\section{REFERENCES}

[1] Gerrettson-cornell, L. (Eds.). 1994. A compendium and classification of the species of the genus Phytophthora de Bary by the canons of the traditional taxonomy. Research division, State forests of new South Wales, Sydney.

[2] Ho, H.H. 1981. Synoptic keys to the species of Phytophthora. Mycologia. 73(4): 705-714.

[3] Diederich, J, Fortuner, R and Milton, J. 2000. Genysis and computer-assisted identification of nematodes. Nematology. 2: 17-30.

[4] Taylor, J.W, Jacobson, D.J, Kroken, S., Kasuga, T, Geiser, D.M, Hibbett, D.S and Fisher, M.C. 2000. Phylogenetic species recognition and species concepts in Fungi. Fung. Gen. Biol. 31, 21-32.

[5] Luc, M, Doucet, M.E, Fortuner, R, Castillo, P, Decraemer, W and Lax P. 2010. Usefulness of morphological data for the study of nematode biodiversity. Nematology. 12: 495-504.

[6] Fortuner, R. 2002. Uniformity and representation of taxonomic and other characters and semi-automatic extraction using computer tools. Nematology. 4: 583591.

[7] Ellis, M.B. 1971. Dematiacious Hyphomycetes. CABI, Kew, UK.

[8] Ellis, M.B. 1976. More Dematiacious Hyphomycetes. CABI, Kew, UK.

[9] Sutton, B.C. 1980. The Coelomycetes. Fungi imperfecti with pycnidia, acervuli and stromata. CABI, Kew, UK.

[10] Hanlin, R.T. 1990. Illustrated genera of Ascomycetes. APS Press. St Paul, USA.
[11] Branett, H.L and Hunter, B.B. 1998. Illustrated genera of imperfect fungi. APS Press, St Paul, USA.

[12] Neilson, H.F and Stewart, T.M. 2003. A multi-access lucid key to common plant pathogenic fungi causing diseases of temperate crops. New Zeal. Plant Protect. 56, 100-102.

[13] Michaelides, J, Hunter, L, Kendrick B and Nag Raj, T.R. 1979. Synoptic key to 200 genera of Coelomycetes. University of Waterloo Biology Series 20. University of Waterloo, Canada.

[14] Korf, R.P and Zhuang WY. 1985. A synoptic key to the species of Lambertella (Sclerotiniaceae) with comments on a version prepared for TAXADAT, Anderegg's computer program. Mycotaxon. 24: 361-386.

[15] Polonelli, L, Gastagnola, M, Rossetti, D.V and Morace, G. 1985. Use of killer toxins for computer-aided differentiation of candida albicans strains. Mycopathologia. 91: 175-179.

[16] Pitt, J.I. 1990. PENAME, a computer key to common Penicillium species. CSIRO Division of Food Processing, North Ryde, NSW.

[17] Thrane, U. 1991. FUSKEY, an interactive computer key to common Fusarium species. Proc. $2^{\text {nd }}$ European Fusarium Seminar, 5-7 Sept. 1990, Poznan Poland.

[18] Bridge, P.D, Kozakiewicz, Z and Paterson, R.R.M. 1992. PENIMAT, a computer-assisted identification scheme for terverticillate Penicillium isolates. Mycol. Pap. 165: $1-59$.

[19] Sarma, V.V, Raghukumar, S, Hyde, K.D, Vittal, B.P.R and Chandramohan, D. 2000. A CD-ROM for documentation and identification of mangrove fungi. In: Hyde KD, Ho WH \& Pointing SB. (eds.), Aquatic Mycology across the Millennium, Fung. Divers. 5. pp. 195-200.

[20] Varese, G.C, Anastasi, A, Voyron, S and Marchisio, V.F. 2010. An interactive tool for the identification of airborne and food fungi. In: Nimis PL, Vignes Lebbe R. (eds.), Tools for identifying biodiversity: progress and problems. Pp. 183-187. University of Torino, Italy.

[21] Tardivel, G.M and Morse, D.R. 1998. The role of the user in computer based species identification. In: Bridge P, Jeffries P, Morse DR, Scott PR (eds.), Information technology, plant pathology and biodiversity. pp. 247259. Wallingford, UK, CAB International.

[22] Tiefenbrunner, A, Tiefenbrunner, M, Tiefenbrunner, W and Wahra, A. 2002. A software tool as an aid to the identification of species of Longidorus Micoletzkey, 1922 (Nematoda: Dorylaimoidea), Nematology. 4: 845852.

[23] Agrios, G.N. 2005. Plant Pathology. $5^{\text {th }}$ ed. Elsevier Academic Press.

[24] Rosenbaum, J. 1917. Studies of the genus Phytophthora. J. Agric. Res. 8: 233-276.

[25] Leonian, L.H. 1925. Physiological studies on the genus Phytophthora. Amer. J. Bot. 12: 444-498.

[26] Tucker, C.M. 1931. Taxonomy of the genus Phytophthora de Bary. Research Bulletin 153, University of Missouri. 
[27] Leonian, L.H. 1934. Identification of Phytophthora species. Research Bulletin 262, University of WestVirginia.

[28] Sarejanni, J.A. 1936. La pourriture du collet des solanees cultivees et la classification du genre Phytophthora. Ann. Inst. Phytopath. Benaki, N. S. 2: 35-51.

[29] Frezzi, M.J. 1950. Las especies de Phytophthora en la Argentina. Rev. Invest. Agr. 4: 47-134.

[30] Waterhouse, G.M and Blackwell, E.M. 1954. Key to the species of Phytophthora recorded in the British Isles. Mycol. Pap. 57.

[31] Waterhouse, G.M. 1963. Key to the species of Phytophthora de Bary. Mycol. Pap. 92.
[32] Newhook, F.J, Waterhouse, G.M and Stamps DJ. 1978. Tabular key to the species of Phytophthora de Bary. Mycol. Pap. 143.

[33] Fogel, R. 1998. Use of the Internet to revive fortunes in Mycology: the MICH experience. Mycologist. 12(2): 6265 .

[34] Fries, E. M, 1821. Systema Mycologicum I. Lund.

[35] Hawksworth, D. L, 1974. Mycologist's Handbook Kew: CMI.

[36] Fortuner, R. 1989. Nematode identification and export system technology. New York, NY, Plenum Publishing Corp, US.

[37] Cheeseman_Day, J, Janus, A and Davis, J. 2005. Computer use and internet use in the United States: 2003 in special studies. US Census Bureau, Washington, D. C.

Table1. Morphologic attributes used in Fungid

\begin{tabular}{|c|c|}
\hline Character & Character states \\
\hline Mycelial growth & $\begin{array}{l}\text { Colony radiate } \\
\text { Colony slightly radiate } \\
\text { Colony without any distinctive pattern } \\
\text { "Chrysanthemun" or Coralloid growth pattern are observed } \\
\text { "petalloid" or floral pattern } \\
\text { "rosse" pattern } \\
\text { "stellate" pattern } \\
\text { Dense white colonies are observed on PDA at } 27^{\circ} \mathrm{c} \\
\text { Mycelium typically gnarled } \\
\text { Less than } 20 \mathrm{~mm} \text { D. growth rate in } 7 \text { days on lima bean agar, equally slow on cornmeal } \\
\text { agar and } 2 \% \text { V-8 agar } \\
\text { Moderate to fast growing } \\
35 \text { mm D. rate at } 32^{\circ} \mathrm{c} \text { on } 5 \% \text { V- } 8 \text { juice agar. Good growth also at } 24^{\circ} \mathrm{c} \\
\text { Growth on the usual media is very slow at } 25^{\circ} \mathrm{c} \\
\text { Cultures with variable aerial mycelium and pattern } \\
\text { Aerial mycelium appressed } \\
\text { Cultures fluffy } \\
\text { Cottony like aerial mycelium over entire colony, faint lobed floral pattern } \\
\text { Less than } 20 \text { mm D. growth rate in } 7 \text { days on oat agar } \\
\text { Less than } 20 \text { mm D. growth rate in } 7 \text { days on potato agar } \\
\text { Hyphae very unequal, often coiling in culture } \\
\text { Granular in appearance } \\
\text { Hyphae irregular., true hyphal swellings not formed } \\
\text { Hyphae intercellular in host, branched } \\
\text { Hyphae intercellular in host, provided with haustoria } \\
\text { Non-septate hyphae in agar media, often swollen in knob like appearance at irregular } \\
\text { intervals }\end{array}$ \\
\hline Cardinal Temperature & Minimum,_Optimum,_Maximum degree \\
\hline Chlamidospore & $\begin{array}{l}\text { Absent, sparse or abundant } \\
\text { Hyaline } \\
\text { Rare terminal } \\
\text { Usually or intercalary terminal } \\
\text { Not observed } \\
\text { Not formed by some isolates, rare to abundant in some others, thick walled } \\
\text { Formed by a lateral swelling of the hyphae, hyaline to amber } \\
\text { Terminal } \\
\text { Thin walled } \\
\text { Apical } \\
\text { Lateral } \\
\text { Spherical } \\
\text { Ellipsoid } \\
\text { Spherical ovoid } \\
\text { Single or crowded }\end{array}$ \\
\hline
\end{tabular}




\begin{tabular}{|l|l|}
\hline & Dark brown \\
\hline Sporangia with more than one exit & Absent \\
tube & Occasionally observed \\
& Occasionally formed with three pores \\
& Rarely observed \\
& Usually formed with two, but even with three or four pores \\
& Present \\
& Formed with two pores \\
\hline
\end{tabular}

\section{Table1. Continued}

\begin{tabular}{|c|c|}
\hline Character & Character states \\
\hline Sexuality & $\begin{array}{l}\text { Heterothallic } \\
\text { Sterile } \\
\text { Rarely homothallic } \\
\text { Homothallic } \\
\text { Predominantly heterothallic }\end{array}$ \\
\hline Hyphal swellings & $\begin{array}{l}\text { Rarely formed or in clusters of a few intercalary elements } \\
\text { Terminal or intercalary } \\
\text { Occasionally formed, terminal sessil or intercalary (the latter in net-like appearance, in } \\
\text { some cultures flooded with water) } \\
\text { Spherical or ovoid or in the shape of sporangia } \\
\text { Not formed } \\
\text { Usually abundant, single or botryose, rarely intercalary, globose and/or more less } \\
\text { irregularly shaped, hyaline to yellowish brown } \\
\text { Sub-spherical to deltoid hyphal swellings } \\
\text { Intercalary in net-like clusters, abundant in clusters flooded with water or aqueous } \\
\text { solutions, they may be elliptical, pyriform, irregular or spherical } \\
\text { Clusters of intercalary swellings, angular to spherical } \\
\text { Thin walled swellings, occasionally cut off by septa may occur } \\
\text { Produced in mycelium transferred to distilled water and incubated for two days under } \\
\text { light } \\
\text { Variable in shape and size } \\
\text { Irregular in shape and size, in chains or clusters } \\
\text { Common in clusters flooded with aqueous solutions, ovoid or spherical, intercalary } \\
\text { Especially in cultures flooded with water spherical, rounded or angular in chains or } \\
\text { clusters } \\
\text { Abundant, rounded, ellipsoid or angular, single or in chains (net-like type), some } \\
\text { germinate to produce germ tubes } \\
\text { Formed abundantly at } 21-24^{\circ} \text { c in agar cultures flooded with water. Round or angular in } \\
\text { chains or clusters } \\
\text { Especially in water, intercalary, spherical, ellipsoidal or angular } \\
\text { Terminal or sessile, globose or sub globose } \\
\text { Spherical to ellipsoid, monilioid or catenulate } \\
\text { Abundant on oatmeal agar, rare on cornmeal agar. Roughly spherical intercalary }\end{array}$ \\
\hline Zoospores & $\begin{array}{l}\text { Present } \\
\text { Migrate into an evanescent vesicle like in the genus Pythium } \\
\text { Presence of lateral hairs on both flagella } \\
\text { Up to } 40-50 \text { zoospores may be produced in a sporangium } \\
\text { Remain inside the sporangium where they germinate } \\
\text { Ellipsoidal or kidney shaped }\end{array}$ \\
\hline Sporangiophore & $\begin{array}{l}\text { Either simple or irregularly branched } \\
\text { Either simple or sympodially branched } \\
\text { Proliferating through the empty sporangium } \\
\text { Each branch ending in short sympodia of } 1-3 \text { sporangia } \\
\text { Umbellate arrangement of sporangia is observed, especially under light conditions of } \\
\text { incubation } \\
\text { Simple } \\
\text { Un-branched } \\
\text { Branched } \\
\text { Irregularly branched } \\
\text { With globose swellings at branching points } \\
\text { Swellings may occur behind the sporangia } \\
\text { Branching compound, sympodial with a small swelling at the base of each branch } \\
\text { Sporangia borne terminally on sporangiophores not differentiated from vegetative hyphae } \\
\text { Loose sympodia } \\
\text { Short, not dissimilar from hyphae }\end{array}$ \\
\hline
\end{tabular}




\begin{tabular}{|l|l|}
\hline & Rather wide compared to the mycelium hyphae, especially beneath the sporangia \\
& Undifferentiated, often with intercalary swellings \\
& Undifferentiated, often with sub-sporangial swellings \\
Branching in a close sympodium, not proliferating, sometimes with intercalary swellings
\end{tabular}

Table 1. Continued

\begin{tabular}{|c|c|}
\hline Character & Character states \\
\hline Sporangia & $\begin{array}{l}\text { Terminal } \\
\text { Intercalary } \\
\text { Ellipsoid } \\
\text { Obtrupinate } \\
\text { Spherical } \\
\text { Semi-papillate } \\
\text { Papillate } \\
\text { Non-papillate } \\
\text { Obpyriform } \\
\text { Deciduous } \\
\text { Non- caduceus } \\
\text { Oval to ovoid } \\
\text { Regular in shape } \\
\text { Non-pedicellate } \\
\text { Distorted shape } \\
\text { Pedicellate } \\
\text { Globose } \\
\text { Sub-globose } \\
\text { Limoniform } \\
\text { Obovate } \\
\text { Pyriform } \\
\text { Large vacuole often present } \\
\text { Papillae usually not exceeding the width of the membrane of the sporangium or slightly } \\
\text { pronounced } \\
\text { Obclavate } \\
\text { One side flattened or cured } \\
\text { Bifurcate or furcate with } 3-4 \text { exit pores } \\
\text { Fusiforme } \\
\text { Elongated } \\
\text { On one side bent or flat } \\
\text { Rather irregular in shape } \\
\text { Rounded apex } \\
\text { Asymmetrical and lateral on stalks with rounded base } \\
\text { With broadest part nearer the apex and tapering towards the base } \\
\text { Obturpinate and ampullate }\end{array}$ \\
\hline Antheridia & $\begin{array}{l}\text { Amphigynous } \\
\text { Unicellular } \\
\text { Bicellular } \\
\text { Often broader than long } \\
\text { Nearly spherical } \\
\text { Paragynous } \\
\text { Close to the oogonial stalk } \\
\text { Nearly spherical toirrgularly shaped } \\
\text { Very variable in shape and size } \\
\text { Spherical to oblong } \\
\text { Oogonia stalk may be occasionally obscured in a knot of hyphae } \\
\text { Spherical to cylindrical } \\
\text { Ellipsoidal }\end{array}$ \\
\hline
\end{tabular}




\section{Table 1. Continued}

\begin{tabular}{|c|c|}
\hline Character & Character states \\
\hline Oospore & $\begin{array}{l}\text { Nearly filling the oogonium } \\
\text { Loose in the oogonium } \\
\text { Hyaline to yellowish brown } \\
\text { Plerotic } \\
\text { Aplerotic } \\
\text { Hyaline to yellowish at the periphery } \\
\text { From aplerotic to nearly filling the oogonium } \\
\text { Hyaline to yellow to tawny } \\
\text { Brownish } \\
\text { Spherical } \\
\text { Honey yellow to brownish when old } \\
\text { Pigmented } \\
\text { Hyaline to faint yellow } \\
\text { Colorless to light brown } \\
\text { The outer wall of the oospore is distinct, thin and much darker than the thick inner wall }\end{array}$ \\
\hline Oogonia & $\begin{array}{l}\text { Wall smooth } \\
\text { Wall wrinkled } \\
\text { Wall bullate or unbullate } \\
\text { Wall verrucose } \\
\text { Wall reticulate } \\
\text { Hyaline } \\
\text { Light brown } \\
\text { Brown } \\
\text { Slightly rough } \\
\text { Yellow } \\
\text { Golden yellow in culture, colorless in host tissues } \\
\text { Formed promptly often in clusters, spherical tapering to stalk } \\
\text { Reddish brown } \\
\text { Colorless } \\
\text { The oogonia stalk is branched sympodially from immediately under the oogonia which } \\
\text { may give the impression of intercalary ogonia } \\
\text { A septum is usually present on many oogonial stalks inside the antheridium } \\
\text { Orange brown } \\
\text { Pyriform } \\
\text { Tapering downwards to a funnel shaped base } \\
\text { Oogonia are terminal but a few intercalary } \\
\text { Occasionally some folds are observed in the membrane }\end{array}$ \\
\hline
\end{tabular}

